\title{
Tradición clásica y ciclo bretón en las órdenes de caballería
}

RESUMEN. La leyenda del rey Arturo sirvió como apoyo propagandístico para legitimar a los monarcas normandos en el trono inglés. La dinastía Plantagenet incrementó esa utilización política a través de la Historia regum Britanniae (1138), escrita en latín por Geoffrey de Monmouth y traducida al francés por Robert Wace con el título de Roman de Brut (h. 1160). En esta traducción aparece la Tabla Redonda, que fue un elemento primordial en la inspiración del espíritu elitista de las órdenes de caballería tardomedievales europeas. La Orden de la Banda Real de Castilla desarrolló las normas de comportamiento caballeresco en la paz y en la guerra; la Orden de la Jarretera se inspiró en el modelo artúrico del Ciclo Bretón, aunque despojado de elementos paganos, y la Orden del Toisón de oro buscó a sus patronos en el Ciclo Troyano y en la Biblia.

Palabras clave: Arturo, Santo Grial, Tabla Redonda, Plantagenet, Banda, Jarretera, Toisón de oro.

ABSTRACT. The legend of King Arthur served as propagandistic support to legitimize the Norman monarchs on the English throne. The Plantagenet dynasty stepped up this political deployment through the Historia Regum Britanniae (1138), written in Latin by Geoffrey of Monmouth and translated into French by Robert Wace with the title of Roman de Brut (c. 1160). The Round Table, a primordial legend in the formation of the elitist spirit of the late medieval chivalric orders, appeared in this translation. The Castilian Order of the Banda Real developed the norms of chivalric behavior in both peace and war; the Order of the Garter took its inspiration from the arthurian model of the Breton cycle, although stripped of its pagan elements, and the Order of the Golden Fleece sought its paradigms in the Trojan cycle and in the Bible.

Key Words: Arthur, Saint Graal, Round Table, Plantagenet, Banda, Garter, Golden Fleece.

A comienzos del siglo XII surge en Europa una nueva sensibilidad estética que en el plano religioso se manifiesta en el culto a la Virgen María, propio del arte gótico y del espíritu cisterciense, y en el plano civil tiene su plasmación en la cultura caballeresca del "amor cortés", fundamentada en valores como la idealización de la mujer amada, el ejercicio de las armas, la defensa de la religión y el socorro a los débiles. Ceremonia y heráldica fueron los componentes visuales y escenográficos de la vida cortesana, en la que el rey, sus caballeros y sus damas, ejercieron de actores principales. En ese ambiente se sublimaron los ideales del caballero cristiano, esbozados por Bonizo de Sutri ${ }^{1}$ hacia el año 1090 en su Liber de vita christiana y codificados con precisión por el beato y caballero

${ }^{1}$ B. DE SUTRI, Liber de vita christiana, Berlín, 1930. mallorquín Raimundo Lulio hacia 1275 en su Libro del Orden de Caballería ${ }^{2}$, donde se lee lo siguiente:

"Se da al caballero una seña para que se fije en el escudo, en la silla y en la túnica, para ser loado por sus ardimientos y hechos de armas en las batallas. Mas si es cobarde, flaco o retraido, por medio de esta misma seña es objeto de burla, vituperado y reprendido".

Tal visión del mundo se había generado a comienzos del siglo XII en los llamados "cantares de gesta", que narraban en lengua romance las hazañas de los grandes héroes del pasado y eran recitados de corte en corte por los trovado-

\footnotetext{
${ }^{2}$ R. Lulio, Libro del Orden de Caballería, Buenos Aires, 1949, p. 73.
} 
res. Las nacientes monarquías europeas encontraban en ellos las virtudes que debían adornar al buen caballero. Así, en España triunfó el Cantar de Mío Cid, en Francia la Chanson de Roland, y en Inglaterra la historia del rey Arturo y sus caballeros de la Tabla Redonda. En la segunda mitad del siglo XII se desarrolla la "épica cortesana", que refleja los hechos de los héroes caballerescos en el mundo refinado y ceremonioso del "amor cortés". Estas novelas caballerescas se agrupan en tres grandes ciclos:

1) La "Materia de Roma", compuesta de historias inspiradas en los textos clásicos. Sus temas principales son la Guerra de Troya, Eneas y Alejandro Magno. En ella, los héroes antiguos son vistos como caballeros andantes contemporáneos.

2) La "Materia de Francia", en la que se trata, de nuevo, de las hazañas de Carlomagno y sus doce pares, ahora más elaboradas y complejas.

3) La "Materia de Bretaña" o "Ciclo Bretón”, que narra las hazañas del rey Arturo y sus caballeros de la Tabla Redonda. Fue la más popular de las tres, al menos en el noroeste de Europa. Desde Gran Bretaña se extendió por el continente a través de los Lais de María de Francia (h. 1160) y de los poemas de Chrétien de Troyes (Perceval ou le conte du Graal, Le chevalier de la charrete, h. 1180), Wolfram von Eschenbach (Parsifal, h. 1210) y Gottfried von Strassburg (Tristan und Isolde $e^{3}$, h. 1210). Ofreció el arquetipo de corte medieval y su estudio es esencial para comprender el espíritu de las órdenes de caballería.

\section{GÉNESIS POLÍTICA Y LITERARIA DEL CICLO BRETÓN.}

En torno al año 410 las legiones romanas abandonaron la provincia de Britania, que fue invadida desde oriente por tres pueblos germanos: anglos, sajones y jutos. Los britanos, tanto los insulares como los continentales, tuvieron que valerse por sí mismos y entre ellos surgió un jefe, llamado Arturo ${ }^{4}$, que según algunos

\footnotetext{
${ }^{3}$ Tristán e Iseo, versión de A. Yllera, Madrid, 1984.

4 A. Berthelot, Arthur et la Table ronde. La force d'une légende, Découvertes Gallimard, n² 298, París, 1996, pp. 12-29.
}

sería un general de la caballería sármata encuadrada en el ejército romano $\mathrm{y}$, según otros, un centurión britano llamado Lucius Artorius Castus. El caso es que a mediados del siglo $\mathrm{V}$ ese Arturo logró unir a las tribus britanas en la lucha contra el invasor, fundando un reino que abarcaba la Gran Bretaña (Gales y Cornualles) y la pequeña Bretaña francesa.

Es posible que Artorius utilizara como enseña el estandarte de la caballería sármata, llamado "draco", consistente en un dragón cuya cabeza de bronce dejaba entrar el viento por la boca, profiriendo un extraño silbido e hinchando una cola tubular de tela. En las Profecías de Merlín ${ }^{5}$, escritas seis siglos más tarde, se identifica al rey Úter Pendragón, padre de Arturo, con el dragón rojo que desde la Baja Edad Media se convertirá en la seña heráldica del País de Gales. Muerto el rey Úter, el dragón rojo (los britanos) es derrotado por el dragón blanco (los sajones), pero éste se encuentra con la fuerte resistencia del jabalí de Cornualles (Arturo), que dominará Britania y los bosques galos. Cuando Arturo muera, resurgirá "el gusano germánico" (el dragón blanco), lloverá sangre y se extenderá el hambre. "Gemirá el dragón rojo ante estos sucesos, pero, después de tanto infortunio, recuperará su vigor" y la calamidad perseguirá al dragón blanco.

En la memoria colectiva permaneció el recuerdo del buen rey Arturo que trajo paz y prosperidad a los britanos. Transmitida de boca en boca durante siglos, la historia se convirtió en leyenda y fue paulatinamente adornada por los bardos con nuevos personajes y lugares, mientras se fundía con las viejas leyendas celtas. Así, la reina Ginebra es un trasunto de la "Reina de las Hadas", soberana luminosa, dotada de poderes mágicos, cuya imagen simbólica fue identificada políticamente a lo largo del tiempo con dos mujeres excepcionales: Leonor de Aquitania e Isabel I de Inglaterra. Del mismo modo, Merlín viene a ser el último druida de la antigua religión que desaparece ante el empuje del Cristianismo. A él se atribuye la construcción del crómlech de Stonehenge (Fig. 1), como monumento solar dedicado a Aurelio Ambrosio, tío de Arturo. El Cristianismo respetará la tradición en las cruces anglo-irlandesas (Fig. 2), que combinan la cruz cristiana con el viejo círculo

\footnotetext{
${ }^{5}$ G. De Monmouth, Historia de los Reyes de Britania, Madrid, 1984, p. 111.
} 
de las divinidades solares. El recuerdo de Roma está presente en la imagen de Camelot, probable trasunto del Muro de Adriano, aunque los historiadores ingleses prefieren identificar la legendaria fortaleza con el castro de Cadbury, en el lugar de Camaalot, donde se han encontrado objetos de los siglos V y VI. Del mismo modo, el Cristianismo aportará a la leyenda los valores caballerescos y el episodio de la búsqueda del Santo Grial o Santo Cáliz que utilizó Jesucristo en la Última Cena.

Pero, ¿cuál fue la razón oculta que motivó el origen de la leyenda?. La respuesta la encontramos en la rivalidad que enfrentaba desde el siglo $\mathrm{V}$ a los britanos autóctonos con los invasores anglosajones ${ }^{6}$. Tal enfrentamiento continuaba vivo en el siglo XI. Así, cuando en 1013 los vikingos daneses conquistaron Inglaterra, hicieron causa común con los anglosajones frente a los britanos. Tres años más tarde moría el rey anglosajón Etelredo II de Wessex y la nobleza elegía como rey al danés Canuto el Grande, que se convirtió al Cristianismo y se casó con Emma de Normandía, viuda del primero. La muerte del rey danés en 1035 trajo consigo luchas sucesorias entre su hijo bastardo Haroldo I, que reinó hasta 1040, y Eduardo el Confesor, hijo de Etelredo II y de la reina Emma, que permaneció exilado en Normandía. Eduardo el Confesor regresó a Inglaterra en 1042, tras ser elegido rey por la nobleza anglosajona, pero puso los principales cargos eclesiásticos, militares y administrativos, en manos de cortesanos normandos y flamencos, para disgusto del partido anglosajón. Como contrapartida, aceptó casarse con la anglosajona Edith, hija del difunto conde Godwin $(+1035)$ y de una danesa.

San Eduardo el Confesor murió el 5 de enero de 1066 sin hijos varones, dejando abierta la lucha sucesoria. El partido sajón eligió como rey al hermano de la reina Edith, Haroldo II Godwinson, que fue coronado en la abadía de Westminster el 6 de enero, pero el partido normando apoyó al duque Guillermo de Normandía, sobrino nieto de la reina Emma. Éste hizo valer sus derechos al trono desembarcando en Inglaterra y derrotando a los sajones en la batalla de Hastings, reñida el 30 de octubre de 1066, en la cual pereció Haroldo II. El duque Guiller-

\footnotetext{
${ }^{6}$ L. Musset, La tapisserie de Bayeux, Zodiaque, París, 1989, pp. 83-89.
}

mo, ahora llamado "el Conquistador", fue coronado como rey de Inglaterra en la abadía de Westminster el día de Navidad de ese mismo año, dando inicio a la dinastía inglesa de reyes anglonormandos. Para consolidar su conquista, los normandos se aliaron con los britanos autóctonos frente al enemigo común, representado por los anglosajones, antiguos invasores de la isla. Esgrimían los britanos un noble origen ligado a la cultura grecorromana y cristiana, frente al origen pagano y bárbaro de los anglosajones. No en vano, el ejército vencedor marchaba tras el estandarte de San Pedro, que era de plata con una cruz potenzada de oro cantonada de cuatro roeles de azur, como se ve en el tapiz de Bayeux. Esta enseña había sido enviada al duque expresamente por el Papa Alejandro II, quien además otorgó a la empresa carácter de cruzada.

En su testamento, Guillermo I el Conquistador (1066-1087) dividió sus posesiones de ambos lados del Canal de la Mancha, dejando el ducado de Normandía a su hijo mayor, Roberto II Courteheuse (1087-1106), y el reino de Inglaterra a su segundo hijo, Guillermo II Rufus (1087-1100). Ambos fueron sucedidos por el hermano más pequeño, Enrique I Beauclerc, rey de Inglaterra (1100-1135) y duque de Normandía (1106), cuyo hijo y heredero, Guillermo, murió ahogado en 1120. Tras esta desgracia, Enrique I no logró que la nobleza anglonormanda aceptase como sucesora a su otra hija, Matilde, esposa del emperador Enrique V de Alemania. Matilde enviudó en 1125 y tres años más tarde se casó con Godofredo Plantagenet, conde de Anjou y de Maine.

Cuando Enrique I de Inglaterra murió, los nobles anglonormandos eligieron a su sobrino Esteban (1135-1154) como rey de Inglaterra, pero el ducado de Normandía fue reclamado por Godofredo Plantagenet en nombre de su esposa Matilde, quien a su vez esgrimió su legítimo derecho al trono inglés. En 1135 Godofredo invadió Normandía y en 1139 su esposa Matilde invadió Inglaterra. En 1141 el ejército de Matilde capturó al rey Esteban en Lincoln y ella fue proclamada reina de Inglaterra por una facción de la nobleza anglonormanda. En 1144 Godofredo Plantagenet conquistó Rouen y fue investido como duque de Normandía. El hijo de Godofredo y de Matilde, llamado Enrique Plantagenet, duque de Normandía y esposo de Leonor, duquesa de Aquitania y condesa de Poitou, fue proclamado rey de Inglaterra por la nobleza 
anglonormanda en 1154, a la muerte del rey Esteban. De este modo, Enrique II y Leonor se convirtieron en señores de un imperio, el angevino, que se extendió desde la frontera escocesa hasta los Pirineos.

Pero los derechos angevinos al trono inglés no eran muy claros y los normandos seguían siendo la minoría dominante en Inglaterra. Por esta razón, Godofredo Plantagenet y, más tarde, su hijo Enrique II de Inglaterra, impulsaron la creación de la leyenda del rey Arturo, para que sirviese como soporte propagandístico de su legitimación como sucesores de los britanos frente a los bárbaros anglosajones. Además, la complicación del sistema feudal quiso que el ahora rey de Inglaterra, Enrique II Plantagenet, fuese a su vez vasallo del rey de Francia, pese a poseer en la misma Francia más territorios que éste. El enfrentamiento con Francia no sólo será político, sino también simbólico, pues, si los Capetos franceses alardeaban de descender de Carlomagno, la dinastía angevina de los Plantagenet esgrimirá ahora como antepasado al todavía más antiguo rey Arturo de Bretaña, recordando que había reinado sobre territorio inglés y francés.

\section{LAS VERSIONES DE MONMOUTH Y WACE.}

El verdadero "creador" de la leyenda del rey Arturo fue el canónigo galés Geoffrey de Monmouth, maestro en el Colegio de San Jorge de Oxford y más tarde obispo de San Asaph (Gales), por el partido de Godofredo Plantagenet. Este clérigo escribió en 1138 la Historia regum Britanniae ${ }^{7}$, en la que narra los orígenes míticos del reino de Britania, cuya fundación atribuye a Bruto, nieto de Ascanio y bisnieto del troyano Eneas. Expulsado de Italia por haber matado a su padre en un accidente de caza, Bruto desembarca en una isla, a la que llama Britania, y funda en ella la ciudad de Nueva Troya (Londres). Más adelante cuenta Monmouth las hazañas de los héroes celtas, como el rey Lear, y narra los hechos de los conquistadores romanos a partir de Julio César, al que hace exclamar interesadamente: “¡Por Hércules! Esos britanos y nosotros, romanos, hemos nacido de

\footnotetext{
${ }^{7}$ Véase el prólogo de Luis Alberto de Cuenca, en: G. De MonMOUTH, ob. cit., 1984, pp. XI-XVII.
}

la misma sangre, puesto que descendemos del pueblo troyano",

Tras llegar a la época de Constantino el Grande, el libro de Monmouth continúa con la historia de los primeros reyes de Britania, entre los que destacan Aurelio Ambrosio, su hermano Úter Pendragón y el hijo de éste, Arturo. A través de esta crónica, Monmouth convirtió al casi olvidado rey Arturo en el arquetipo de soberano perfecto y en el modelo a seguir para los reyes de la dinastía Plantagenet. Además, integró en esta historia las Prophetiae Merlini, obra que él mismo había escrito hacia 1132 para establecer una continuidad histórica entre el rey Arturo y los soberanos normandos de Inglaterra. Con ello daba a entender que el renacimiento bretón solamente sería posible a través del apoyo de los britanos a la causa normanda, frente al común enemigo anglosajón.

Para componer su Historia de los Reyes de Britania, Monmouth se basó en las fuentes literarias y en la tradición oral:

\section{FUENTES CLÁSICAS Y CRISTIA- NAS:}

- Cicerón, Virgilio, Estacio, Juvenal, Lucano, Apuleyo, Floro y Orosio.

- $\quad$ La Biblia.

\section{FUENTE ANGLOSAJONA:}

- Historia ecclesiastica gentis Anglorum, de Beda el Venerable (673-735).

\section{FUENTES BRITANAS:}

- De excidio et conquestu Britanniae, de Gildas (h. 550). Narra la destrucción de Britania, causada por la decadencia de las costumbres. Presenta a un Arturo que derrota a los paganos sajones, pero tiene enfrentamientos con el clero cristiano.

- La Historia Britonum, atribuida a Nenio (h. 800), donde empieza a destacar la figura de Arturo como guerrero cristiano que derrota en doce batallas a los paganos sajones de Kent. En la última, Arturo y Mordred se matan mutuamente.

\footnotetext{
${ }^{8}$ G. De Monmouth, ob. cit., 1984, p. 53.
} 
Los Annales Cambriae (s. X), que presentan a un Arturo cristiano vencedor en doce batallas, llevando a la Virgen María pintada en el interior de su escudo. Sitúan la batalla de Camlann, la última de las doce, en el año 537.

- Crónicas del siglo XII: La Gesta Regum Anglorum (h. 1127), de Guillermo de Malmesbury, y la Historia Anglorum (h. 1150), de Enrique de Huntingdon.

- Tradición oral: viejas leyendas britanas y celtas.

El resultado final superó todas las previsiones, pues la leyenda traspasó fronteras y la corte del rey Arturo se convirtió en paradigma de los valores caballerescos occidentales y en el modelo a imitar en todas las cortes europeas. De hecho, la elaboración de la Historia regum Britanniae coincidió en el tiempo con la difusión de la poesía del "amor cortés", impulsada desde la corte refinada de Leonor de Aquitania ${ }^{9}$ (h. 1122-1204), nieta de Guillermo IX, llamado “el primer trovador". Inteligente y bella, Leonor hablaba latín, francés, bretón y las lenguas de "Oc" y de "Oill", pues había crecido entre trovadores aquitanos y occitanos, bardos armoricanos y poetas andalusíes. Gracias al apoyo de San Bernardo, en 1152 se divorció del rey Luis VII de Francia, su primer marido, y dos meses más tarde contrajo matrimonio con el joven Enrique Plantagenet, duque de Normandía y conde de Anjou y de Maine, del que se había enamorado en una fiesta. Luis VII se dio cuenta entonces del grave error que había cometido al divorciarse, pues los principales feudos del oeste francés escapaban ahora a su control. Su miedo crecería notablemente en 1154, cuando los nuevos esposos pasaron a reinar sobre Inglaterra.

Pese a su juventud, Enrique II Plantagenet era un hábil político que hablaba francés, latín y occitano, le gustaba rodearse de poetas y trovadores y destacaba en los ejercicios caballerescos, como la caza y los torneos. Su matrimonio con Leonor de Aquitania resultó muy beneficioso para el desarrollo de la cultura europea, pues produjo un rico intercambio cultural entre el sur de Francia, Normandía e Inglaterra. Tal

\footnotetext{
9 Véase: J. MARKALE, Leonor de Aquitania (París, 1979), Barcelona, 1999 ( $3^{\mathrm{a}}$ ed.).
}

intercambio posibilitará la difusión del Ciclo Artúrico por toda Europa a través de la traducción del texto latino de la Historia regum Britanniae, que sólo era comprensible para el clero cultivado, a las lenguas romances, que permitirían llevarlo a un público mucho más amplio. Consciente de las posibilidades propagandísticas que esto traía consigo, Enrique II de Inglaterra promovió una traducción manipulada de la leyenda del rey Arturo para ganarse el apoyo de los galeses y los bretones, teniendo en cuenta que era necesario modificar el episodio según el cual Arturo resulta herido mortalmente en la batalla de Camlann y es trasladado por el hada Morgana a la isla de Avalón para curar sus heridas, lugar desde donde regresará en un futuro para liberar de la tiranía a los britanos.

Enrique II encargó hacia 1155 al clérigo normando Robert Wace, natural de Jersey, que tradujese al francés la Historia regum Britanniae. La traducción recibió el título de Roman de Brut, en alusión al mítico fundador de Britania, y sirvió como modelo para la traducción inglesa de Layamon. En esta obra, Arturo es el héroe invencible que empuña la espada "Caliburn", embraza un escudo con la imagen pintada de la Virgen María, derrota a los sajones, conquista la Galia y rivaliza en poderío con el Imperio Romano. Pero Wace inventa un interregno de doce años de paz entre el final de las guerras sajonas y el paso de Arturo al continente, donde introduce narraciones cortas que reflejan las maravillas de la corte de Bretaña. En esta parte inventa el autor la Tabla Redonda, donde Arturo se sienta en condiciones de igualdad con doce caballeros. Llegados al espinoso final de Arturo malherido, Wace introduce la duda sobre el lugar donde se encuentra Avalón y se pregunta si Arturo seguirá allí después de tanto tiempo. En el plano de la realidad, Enrique II identificó interesadamente la mítica Avalón con la Abadía galesa de Glastonbury, que recientemente había sido pasto del fuego. Hizo notar que Glastonbury (en galés, "Inys Wytrin") significa "Isla de Cristal", que es una de las acepciones de Avalón, y potenció la leyenda de que había sido la primera iglesia fundada en Inglaterra por José de Arimatea cuando llegó con sus discípulos desde Jerusalén con el Santo Grial. Al mismo tiempo, extendió el rumor de que las hadas no habían podido curar a Arturo y habían devuelto su cuerpo muerto a la costa galesa tres días después de la batalla final. 
Los propios monjes benedictinos de Glastonbury colaboraron de buen grado en la operación propagandística, pues las donaciones de Enrique II les habían salvado de la ruina económica, convirtiendo a su monasterio en uno de los más ricos de Inglaterra. Esta colaboración prosiguió tras la muerte del monarca, acaecida en 1189 . Dos años más tarde, los propios monjes de Glastonbury extendieron la noticia de que habían "descubierto" en el cementerio de su abadía la auténtica tumba de Arturo y Ginebra, la cual fue abierta con gran pompa en presencia de los prelados y cortesanos ingleses. En su interior se encontró una pareja de esqueletos, conservando el de la mujer una hermosa cabellera dorada. Junto a ellos había una cruz que contenía una inscripción con sus nombres y que desapareció misteriosamente poco después. Con esta operación se eliminó definitivamente la "esperanza bretona" del regreso de Arturo y se garantizó la "autenticidad" histórica de la leyenda y del propio Arturo, ligándola a la dinastía de los Plantagenet.

\section{LA TABLA REDONDA Y EL SANTO GRIAL.}

Como apuntábamos más arriba, la Tabla Redonda aparece por primera vez en el Roman de Brut, escrito hacia 1160 en francés por Robert Wace, canónigo de la catedral de Bayeux. Está inspirada en la imagen de Carlomagno rodeado de sus doce pares, que a su vez se inspira en la de Jesucristo y los doce apóstoles sentados a la mesa durante la Última Cena. Su forma circular entronca con la tradición solar del mundo celta, visible en el crómlech de Stonehenge y en las cruces medievales anglo-irlandesas, donde el círculo es un símbolo del poder divino y humano, y posibilita que Arturo y la élite de sus caballeros se sienten a ella durante las reuniones y banquetes en condiciones de igualdad, evitando problemas de precedencia. Tenía en principio doce asientos, pero los libros artúricos que se escriben posteriormente ${ }^{10}$ van añadiendo nuevos personajes a la historia, de modo que en las versiones tardías llega a haber trescientos sesenta y seis asientos.

\section{-}

${ }^{10}$ Sobre el Ciclo Artúrico, véase: C. Alvar, El Rey Arturo y su Mundo. Diccionario de Mitología Artúrica, Madrid, 1991; J. Boulenger, La Légende du Roi Arthur et des chevaliers de la Table Ronde, 2 vols., La Flèche, 1999; M. Pastoureau, Les chevaliers de la Table Ronde. Histoire d'une societé imaginaire, Doussard, 2005.
También evoluciona su significado simbólico $^{11}$. Así, en la versión de Wace la Tabla Redonda representa el orden cósmico, pues "rueda como el mundo" y se sientan a ella los doce reyes del mundo, pero en versiones posteriores pierde su carácter mágico y se convierte en un simple lugar de reunión para caballeros principales. Recupera su sentido místico con la aparición de la leyenda del Santo Grial, objeto sagrado cuya primera mención encontramos en el Perceval de Chrétien de Troyes, escrito hacia 1180. En esta obra, Perceval asiste a un banquete celebrado en el castillo del "Rey Pescador", donde ve un cortejo formado por un paje que lleva una lanza sangrante, una doncella que trae el Grial y otra que porta una bandeja de plata. El protagonista debe preguntar por el significado de este cortejo, pero no llega a hacerlo a causa de su aguda timidez, de modo que impide la curación del "Rey Pescador". Cuando abandona el castillo, una doncella le revela el contenido del Grial, que no es sino la Hostia consagrada.

No aclaró mucho más Chrétien de Troyes sobre el significado del Grial, pero en la Estoire dou Graal, escrita por Robert de Boron a comienzos del siglo XIII, ya se dice que ese recipiente fue el cáliz con el que Jesucristo instituyó el sacramento de la Eucaristía durante la Última Cena. Tras la muerte de Cristo en la cruz, José de Arimatea recogió en el mismo cáliz la Santa Sangre y se llevó consigo la preciada joya a tierras britanas. También es Boron quien convierte a Merlín en el principal impulsor del proceso de cristianización del Ciclo Artúrico. El curioso personaje aparecía ya como profeta o mago en tres obras de Monmouth: Prophetiae Merlini (h. 1132), Historia regum Britanniae (h. 1338) y Vita Merlini (h. 1150), donde intervenía en la concepción de Arturo, al preparar el bebedizo que otorgó al rey Úter Pendragon la apariencia física de Gorlois, duque de Cornualles, para que pudiera yacer con la esposa de éste, Igerna, en el castillo de Tintagel $^{12}$.

La figura de Merlín tiene su origen en dos leyendas celtas del siglo VI. Es el resultado de la fusión del Merlinus Ambrosius, vidente y caudillo militar, que vive en el frondoso robledal bretón de Broceliande, y del Myrddin druida, mago y poeta profético, residente en los

\footnotetext{
11 A. BERTHELOT, ob. cit., 1996, pp. 56-57.

12 G. DE MonMOUTH, ob. cit., 1994, pp. 139-142.
} 
bosques galeses ${ }^{13}$. Según Boron, Merlín funda la Tabla Redonda para acoger en ella a la élite de los caballeros cristianos, tomando como modelo la imagen evangélica de la Última Cena y la legendaria "Mesa del servicio del Grial" fundada por José de Arimatea para distinguir, gracias al designio del propio Grial, a los discípulos que debían acompañarle en su largo periplo desde Jerusalén hasta Britania ${ }^{14}$.

La Morte D'Arthur, escrita en la cárcel por Sir Thomas Malory ${ }^{15}(+1471)$ e impresa en Londres por William Caxton en 1485, ofrece la versión definitiva de la Tabla Redonda, señalando que fue fundada por Merlín "en representación de la redondez del mundo", pues acogía a los mejores caballeros del orbe, ya fueran paganos o cristianos, que querían formar parte de ella aun a costa de dejar atrás a sus familias. Dichos caballeros conocerían "la verdad del Santo Grial", pero sólo tres de ellos encontrarían la preciada reliquia y serían testigos del milagro de la Transustanciación. Merlín les identifica con "tres toros blancos... y dos de ellos serían donceles, y que el tercero sería casto". Para este último, Merlín reservó en la Mesa Redonda la "Silla Peligrosa", que permanecerá vacía hasta que en ella se siente "aquel que sobrepuje a todos los caballeros".

Un juramento une al rey y a sus caballeros de la Tabla Redonda en un sentimiento de fraternidad indisoluble, que sólo acaba rompiéndose en las trágicas circunstancias de la batalla final. En recuerdo de Judas permanece vacío el "Sitial Peligroso", trono dorado del que surgen llamaradas de fuego, cuyo origen simbólico podría encontrarse en la "Lia Fail" irlande$\mathrm{sa}^{16}$, una piedra de soberanía que grita cada vez que un nuevo soberano la pisa. El "Sitial Peligroso" está reservado al caballero más puro, al único capaz de encontrar el Santo Grial. El indigno caballero Brumante el Orgulloso osa sentarse en él y al punto se ve reducido a cenizas por el fuego, ante el asombro de los presentes. Según Malory, el día de Pentecostés del año 445 acude a la Mesa Redonda un anciano vestido de blanco que trae consigo al joven caballero Galahad (Fig. 3). El anciano levanta el paño de

\section{-}

${ }^{13}$ C. AlVAR, ob. cit., 1991, pp. 296-299.

${ }^{14}$ A. BeRTHELOT, ob. cit., 1996, pp. 56-57.

${ }^{15}$ T. MALORY, La muerte de Arturo, 2 vols., Madrid, 1999 ( $2^{\mathrm{a}}$ ed.), pp. 270-271.

${ }^{16}$ A. BeRTHELOT, ob. cit., 1996, p. 57. seda que cubre el "Sitial Peligroso" y todos los presentes ven grabada en su respaldo una frase que dice: "este es el sitio de Galahad". Tras sentarse en él, Galahad es reconocido por Arturo y sus caballeros como el destinado a concluir la búsqueda del Santo Grial ${ }^{17}$. En la leyenda, Sir Galahad es hijo del bretón Sir Lancelot y de Elaine, la hija de Pelles, el "Rey Pescador" y, por lo tanto, desciende de José de Arimatea, de Salomón y de David.

Sigue contando Malory ${ }^{18}$ que después de una justa celebrada en el prado cercano a Camelot, en la que Sir Galahad quebró más lanzas que ningún otro, el rey Arturo y sus caballeros asistieron a vísperas en la capilla del castillo. Más tarde, se sentaron todos juntos en la Tabla Redonda para cenar, siendo testigos de la aparición milagrosa y deslumbradora del Santo Grial (Fig. 4), que les alimentó con la Gracia divina:

"Entonces entró en la sala el Santo Grial cubierto con jamete blanco, pero nadie pudo verlo, ni quién lo llevaba. Y toda la sala se llenó de fragancia, y cada caballero tuvo las viandas y bebidas que más amaba en este mundo. Y cuando el Santo Grial hubo sido paseado por toda la sala, entonces el vaso sagrado desapareció súbitamente, de manera que no supieron qué había sido de él; y al punto recobraron todos el aliento para hablar. Y el rey dio gracias a Dios por la buena gracia que les habia enviado...".

Como ninguno de los presentes pudo ver el Santo Grial, Sir Gawain juró partir en su búsqueda y los demás caballeros hicieron la misma promesa, pero sería Sir Galahad, el puro entre los puros, el único capaz de encontrarlo. Esto ocurrió en el castillo de Carbonek, donde Sir Galahad, Sir Perceval, Sir Bors, mas tres caballeros galos, tres irlandeses, tres daneses y el "Rey Tullido", que estaba tendido en su lecho de enfermo, vieron cómo cuatro ángeles traían a José de Arimatea, vestido de obispo y sentado en una cátedra, y le dejaban ante la mesa de plata en la que estaba colocado el Santo Grial. También entraron cuatro ángeles: dos de ellos llevaban cirios, el tercero un paño y el cuarto la Santa Lanza de Longinos, "que sangraba prodigiosamente, de manera que tres gotas cayeron

\footnotetext{
${ }^{17}$ T. MALORY, ob. cit., vol. II, 1999, pp. 233-239.

${ }^{18}$ Ibid., vol. II, 1999, pp. 241-243.
} 
dentro de una arqueta que sostenía en su otra mano. Pusieron los cirios sobre la mesa, y el tercero el paño sobre el vaso, y el cuarto la Santa Lanza derecha sobre el vaso".

José de Arimatea consagró el pan, en cuyo interior se metió una figura semejante a un niño de rostro bermejo, "de manera que todos vieron que el pan estaba formado de una persona carnal". Después introdujo el pan consagrado dentro del Santo Grial, besó a Sir Galahad y le ordenó que diese el beso de la paz a sus compañeros. Para terminar, les advirtió que serían alimentados "con confituras que jamás han probado los caballeros". Dicho esto, desapareció, y los temerosos caballeros se sentaron a la mesa. De pronto, vieron a Jesucristo surgiendo del Santo Grial y fueron alimentados con su sangre, "y les pareció tan dulce que sería maravilla contar"19. Jesús entregó a Sir Galahad el plato sagrado donde comió el Cordero el Jueves de Pascua y le encargó llevar el Grial lejos del reino de Logres, donde se encontraban, "porque no ha sido servido y honrado como debe ser por los de esta tierra, pues están inclinados a vivir mal". También le mandó tomar un barco y llevar consigo otros dos objetos sagrados: la espada del Extraño Ceñidor, que perteneció a Salomón y es el símbolo de la Sagrada Escritura, y la sangre de la Santa Lanza, "para ungirle al Rey Tullido las piernas y todo el cuerpo, y que recobre la salud". Finalmente le ordenó que viajase con dos compañeros: Sir Perceval y Sir Bors.

Galahad curó al "Rey Tullido" y embarcó con sus dos compañeros en la nave de Salomón, donde encontraron el Santo Grial cubierto con jamete bermejo y colocado sobre la mesa de plata. Durante el viaje, Galahad suplicó al Señor que le permitiese dejar este mundo cuando lo desease. En respuesta, una voz le dijo que "cuando pidas la muerte de tu cuerpo la tendrás, y entonces hallarás la vida del alma". Desembarcaron en la ciudad de Sarras, pero fueron encarcelados por orden del rey Estorause, que era pagano. Permitió entonces el Señor que el Santo Grial se apareciese a los prisioneros, de modo que durante su cautiverio nunca les faltó el dulce alimento de la Gracia divina.

Al morir el tirano Estorause, los habitantes de Sarras eligieron a Galahad como nuevo

\footnotetext{
${ }^{19}$ Ibid., vol. II, 1999, pp. 354-363.
}

rey. Éste les ordenó que construyesen "sobre la mesa de plata un armario de oro y piedras preciosas", para guardar el Santo Cáliz. Un año más tarde, el rey Galahad acudió temprano con sus dos compañeros a la sala palatina del Santo Grial. Allí encontraron a un hombre arrodillado, vestido de obispo y rodeado de ángeles, "como si fuese el mismo Jesucristo". El misterioso personaje ofició una misa dedicada a Nuestra Señora y se identificó ante Galahad como José, hijo de José de Arimatea, anunciándole que su deseo de dejar este mundo se iba a cumplir y que el Señor le había enviado para hacerle compañía, pues, como él, también había visto las maravillas del Santo Grial y era doncel puro. Dicho esto, Sir Galahad se despidió de Sir Perceval y de Sir Bors, se arrodilló ante el Santo Grial, rezó sus preces y "su alma partió súbitamente hacia Jesucristo", siendo elevada a los cielos por un gran número de ángeles. Perceval y Bors vieron también cómo una mano surgía de la luz y se llevaba el Santo Grial y la Santa Lanza a los cielos. Desde entonces "jamás hubo hombre tan osado que dijera que había visto el Santo Grial”.

Todavía se discute sobre el origen simbólico del Santo Grial ${ }^{20}$. Podría proceder de la transformación estética y religiosa del caldero circular que utilizaban los celtas paganos en sus ritos de fertilidad. Paulatinamente, ese caldero se iría adaptando a las exigencias de la religión cristiana, hasta convertirse en el Cáliz de la Última Cena, manteniendo vivo -y ligeramente soterrado- su antiguo significado pagano de centro de irradiación del poder en torno al cual se reunían el rey y sus notables.

Con la aparición de Galahad en la leyenda artúrica, el Santo Grial se convierte en el símbolo de la Caballería Celeste, entroncando con el concepto del monje-guerrero, revestido de doble armadura de hierro y de Fe cristiana, al que se había referido Bernardo de Claraval en su sermón De Laude Novae Militiae, pronunciado en 1136 en favor de la Orden del Temple ${ }^{21}$.

\footnotetext{
${ }^{20}$ A. Berthelot, ob. cit., 1996, p. 17; J. EvOla, El Misterio del Grial, Barcelona, 2001.

${ }^{21}$ SAn BernARDO, "Liber ad Milites Templi. De Laude Novae Militiae", Obras completas de San Bernardo, t. I, Madrid, 1983, pp. 496-543. Sobre la Orden del Temple, véase: L. GARCíA-GuiJarro RAmos, Papado, Cruzadas y Órdenes Militares, siglos XI - XIII, Madrid, 1995, pp. 70-122; R. PERnOud, Les Templiers, chevaliers du Christ, Découvertes Gallimard, no 260, París, 1996.
} 
San Bernardo hace distinción entre lo que llama irónicamente "malitia", o milicia secular, compuesta por los caballeros mundanos, que sólo se mueven por odio y ambición, y la "militia" verdadera, dedicada a la defensa del Cristianismo y a la conservación de los Santos Lugares mediante la lucha armada contra los infieles. Los que caigan en esta lucha ganarán el cielo. Con tal concepción ascética y salvífica del uso de las armas, que se inspiraba en la "yijad" del enemigo musulmán, se pretendía canalizar la violencia de la sociedad feudal europea hacia objetivos externos, como reconoce en su sermón el propio abad cisterciense, para quien los caballeros templarios deben ser ascetas, castos y solidarios en su comportamiento, amén de leales y obedientes a su gran maestre Hugo de Payens, a fin de fortalecer la unidad de una Orden en cuyo seno se deben eliminar las diferencias sociales.

El fracaso de las cruzadas convirtió a la Orden del Temple en un obstáculo para las ambiciones de Felipe IV el Hermoso, rey de Francia, que deseaba hacerse con sus enormes riquezas. El 13 de octubre de 1307 hizo detener al gran maestre Jacques de Molay y dio inicio a un proceso en el que la Orden fue acusada de practicar cultos demoníacos. También consiguió que el Papa Clemente V (Bertrand de Got) disolviera la Orden en 1312, durante el Concilio de Viena, pese a la oposición de la mayoría conciliar. Sin perder tiempo, el monarca francés se apropió ilegalmente de todos los bienes que la Orden poseía en Francia, ignorando la disposición pontificia que exigía entregarlos a la Orden de San Juan. El maestre Molay confesó bajo tortura, pero más tarde se declaró inocente, razón por la cual el 18 de marzo de 1314 fue quemado vivo en la hoguera junto a su lugarteniente, Godofredo de Charnay, mientras clamaba por su inocencia ante los parisinos y profería una maldición contra el rey de Francia y el Papa de Aviñón. La leyenda señaló que los Templarios, además de custodios del Templo de Salomón, lo habían sido del Santo Grial..., y lo cierto es que el Papa murió el 20 de abril de 1314 y Felipe IV el Hermoso el 29 de noviembre del mismo año.

La difusión literaria del Ciclo Artúrico en el Sacro Imperio culminó en el poema Parsifal, escrito por Wolfram von Eschenbach hacia 1210. En su primera parte sigue bastante fielmente el Perceval de Chrétien de Troyes, pero Eschenbach crea una historia original en torno al Santo Grial, convirtiéndolo en la "Piedra de la Luz" que fue traída del cielo por los ángeles condenados a descender a la tierra porque se mantuvieron neutrales durante la rebelión de Lucifer, los cuales, después de la Última Cena y de la Crucifixión, se la entregaron a una estirpe de caballeros guardianes ${ }^{22}$. En el poema Der Wartburgkrieg, escrito a mediados del siglo XIII, se afirma que esa piedra se había desprendido de la corona de Lucifer ${ }^{23}$ cuando fue expulsado del cielo por Dios. Otra fuente habla de una esmeralda desprendida de la frente de Lucifer y tallada en forma de copa por un ángel que se la entregó a Adán, quien la perdió al ser expulsado del Paraíso. En todo caso, se impuso la idea de un Grial dotado de poderes mágicos y custodiado por una estirpe de caballeros guardianes. Por desgracia, esta idea arraigó en los peores anhelos pseudomísticos del nacionalismo pangermánico $^{24}$, cuyos seguidores creyeron ver en el Santo Grial un talismán cuya posesión permitiría dominar el mundo.

\section{LA ORDEN DE LA BANDA REAL DE CASTILLA.}

Esta simbología elitista y religiosa influyó en la creación de las órdenes laicas de caballeros que aparecieron durante el siglo XIV, cuando la caballería alcanzaba su apogeo y entraba en crisis, debido a la participación de los arqueros en las batallas. Las cruzadas habían fracasado y Europa iba a sufrir el azote de la Guerra de los Cien Años, motivada por la pretensión de los reyes ingleses al trono francés. Al contrario de lo que ocurría en las órdenes militares, cuyas reglas exigían celibato y vida monástica, las órdenes de carácter laico iban a ser hermandades cortesanas fundadas y presididas por el propio rey, aunque estarían sometidas a la aprobación pontificia. Se identificarían mediante una divisa que sería concedida por el soberano a un grupo escogido de caballeros, a cambio de un juramento de fidelidad y de la sumisión a unos estatutos escritos en los que se especificarían sus derechos y obligaciones. En realidad, lo que parecía un juego cortesano, consistente en recrear la hermandad de la Tabla Redonda del

\footnotetext{
${ }^{22}$ W. VON EschenBach, Parsifal. Citado en: J. EvoLA, ob.cit., 2001, p. 80

${ }^{23}$ ANÓNIMO, Der Wartburgkrieg, ed. de K. Simrock, Stuttgart, 1858, pp. 174-178, 142-145. Citado en: J. EvOLA, ob. cit., 2001, pp. 80-81.

24 Véase: O. RAHN, Kreuzzug gegen den Gral, Stuttgart, 1964 (1 $1^{\mathrm{a}}$ ed., 1933).
} 
Ciclo Artúrico, iba a convertirse en un instrumento político de centralización del poder que sería utilizado por el monarca para controlar a la alta nobleza.

La más antigua de las órdenes laicas europeas fue la Orden de la Banda Real de Casti1la. La fundó el rey don Alfonso XI de Castilla en Guadalajara, en 1332, por las razones que se explican en el Libro de la Banda, que él mismo ordenó escribir, donde se contienen las reglas y constituciones de la Orden. En sus páginas no se hacen referencias a mitos literarios concretos, pero se subrayan las principales virtudes del mundo caballeresco -VERDAD, LEALTAD y DEFENSA DE LA FE CRISTIANA-, que deben observar los caballeros de la Banda con mayor rigor, pues son los más selectos de la corte. No se menciona el Ciclo Artúrico, que en España tuvo poca difusión, aunque el clima de exaltación religiosa propio de la Reconquista sí había reparado en el episodio de la "Demanda del Santo Grial" 25 . Nada de esto se refleja en los estatutos de la Orden de la Banda, pero en ellos se insiste en la defensa de la Fe Católica ${ }^{26}$ :

"E la razón por que se movió a fazerlo [Alfonso XI] es porque la más alta e más preciada orden que Dios en el mundo fizo es la caballería; y esto por muchas razones, señaladamente por dos: la primera porque la fizo Dios para defender su fe; la segunda, otrosí para defender cada uno sus comarcas e sus tierras e sus estados".

"E por esto se fizo esta Orden de la Vanda, por que los caballeros que quisieren ser en esta orden e tomar la van$d a$, que mantengan estas tres cosas más que otros cavalleros: ser leales a sus señores, e amar lealmente a aquel en quien pusieren su coraçón, e tenerse por cavalleros más que otros para fazer más altas cavallerías".

-

${ }^{25}$ Dicen las fuentes hispánicas que el Santo Grial, custodiado en un principio por José de Arimatea, fue llevado por San Pedro a Roma, desde donde lo envió el diácono Lorenzo a Huesca, para salvarlo de la persecución de Valeriano. Durante la invasión árabe permaneció oculto en el monasterio de San Juan de la Peña. Martín I el Humano se lo llevó a Zaragoza en 1399, Alfonso V el Magnánimo lo trasladó a Valencia y en 1437 Juan II de Navarra se lo entregó a la catedral valenciana, donde todavía está

${ }^{26}$ A. DE CARTAgena, Doctrinal de los cavalleros, ed. de J. M. Viña, Santiago de Compostela, 2000, pp. 229-240.
Alfonso XI eligió como divisa de la Orden de la Banda un escudo de plata con una banda de sable engolada en dragantes de sinople, pero ya en 1348 esos esmaltes se habían tornado en gules para el campo y oro para la banda engolada (Fig. 5), que eran los colores heráldicos de Castilla ${ }^{27}$. De hecho, los caballeros de esta Orden vestían túnica escarlata con una banda dorada que desde el hombro derecho cruzaba pecho y espalda hasta el costado izquierdo (Fig. 6). Eran nombrados por el rey en una ceremonia que requería la presencia de un mínimo de seis caballeros de la Banda. El nuevo cofrade juraba lealtad al rey y amistad a los caballeros de la Banda. Se dice en los estatutos que a continuación el neófito "finque las rodillas; e tome el rey e los cavalleros de la Vanda que i estovieren las sobreseñales de la Vanda con las manos e vístangelas; e después que fuere vestido, que abrace a todos los cavalleros de la Vanda que i estovieren, e que los aya por sus hermanos dende en adelante. E otrosí le digan que Dios ponga en su talante y en su coraçón de guardar todas las cosas que dizen en este libro que han de guardar los cavalleros de la Vanda". Quedaba también obligado a guardar secreto sobre los estatutos contenidos en el Libro de la Banda, so pena de no poder traer la banda durante tres meses ${ }^{28}$.

En el citado Libro de la Banda se incluyen las normas de comportamiento ${ }^{29}$ que deben observar los caballeros. Así, en el plano religioso, el caballero de la Banda está obligado a oír misa diaria cada mañana. En la paz y en la guerra debe ir "bien guisado del mejor cavallo e de las mejores armas e más loçanas que podiere haber", llevando siempre la banda en su vestido y en las gualdrapas de su caballo, y pendón en la lanza. Aunque no vista armadura, siempre llevará espada o misericordia, "e cuando comiere, que siempre tenga la espada cabe sí”. No jugará a los dados cuando anduviere en guerra. No se quejará del dolor de sus heridas. Tendrá el andar sosegado y hablará con tino, sin voces y "non muy apriesa". Defenderá a las dueñas y doncellas hidalgas y no dirá agravio alguno contra la que se le muestre arisca. No comerá frutas ni hortalizas "torpes e suzias", ni comerá viandas

\footnotetext{
${ }^{27}$ G. J. DE OSMA, Las divisas del Rey en los pavimentos de <<obra de Manises $>>$ del Castillo de Nápoles (años 1446-1458), Madrid, 1909, p. 42.

28 A. de CARTAGENA, ob. cit., 2000, pp. 233-234, 240.

${ }^{29}$ Ibid., 2000, pp. 231-233, 236.
} 
sin que haya manteles en la mesa. Tampoco beberá de pie, "salvo si bebiere agua", ni beberá vino "en cosa de barro nin de madera". Cuando dos caballeros de la Banda disputen entre sí haciendo uso de sus espadas, el culpable se verá privado de la merced del rey durante dos meses, en los cuales solo podrá vestir "media vanda en las espaldas". Si hirió a su compañero, quedará privado de toda merced del rey durante un año, en el que deberá llevar dicha media banda en las espaldas.

También se especifica ${ }^{30}$ que los caballeros de la Banda deberán reunirse al menos tres veces al año, que serán en Pascua florida, San Juan de junio y Navidad, anticipando lo que serán las reuniones capitulares de las órdenes europeas posteriores. Como maestre de la Orden, el rey pasará revista a caballo a los caballeros, que acudirán perfectamente armados a la cita. Después comerá con ellos y presidirá el torneo preparado al efecto, cuyas reglas también se especifican detalladamente en el Libro de la Banda. Daba el torneo ocasión a algunos caballeros para ganar la banda. El aspirante debía enfrentarse dos veces en la liza con cada caballero de la Banda. Si derrotaba a todos o, al menos, no se caía del caballo ni perdía la espada, podía vestir la banda "dende en adelante".

Este interés en los torneos era propio del mundo de la caballería. Como es sabido, los torneos comenzaron a celebrarse a mediados del siglo XI en tierras normandas y en ellos eran frecuentes las muertes accidentales, pese a que resultaba más rentable hacer prisioneros para cobrar rescate. Ya en el Concilio de Letrán de 1139, Inocencio II prohibió que se diese sepultura en sagrado a todo caballero que muriera torneando, de modo que a comienzos del siglo XIII se creó una normativa que garantizaba un comportamiento "deportivo", o lo que es lo mismo, caballeresco, entre los contendientes. Muchos torneos fueron denominados entonces "tablas redondas" y se celebraron en una atmósfera que trataba de recrear el mundo legendario del rey Arturo, pero como seguían provocando disturbios e incitando al pecado carnal, fueron prohibidos por el Papa Clemente IV (12651268) para evitar la muerte inútil de los caballeros cristianos, cuyo deber era combatir contra los infieles en Tierra Santa. El Papa Juan XXII (1316-1334) volvió a permitirlos, siempre que

\footnotetext{
${ }^{30}$ Ibid., 2000, pp. 235-239.
}

estuviesen sujetos a un reglamento que garantizase la seguridad de los participantes y de sus caballos, que eran muy costosos. Se estableció un sistema de puntuación, basado en el número de lanzas rotas contra la armadura del adversario, y se prohibió golpear debajo de la cintura y herir o matar al caballo. Este regreso de los torneos a la legalidad es lo que motivó el nacimiento de la Orden de la Banda.

Esta Orden admitió damas en su seno desde que el rey don Juan I de Castilla concedió a las mujeres nobles de Palencia permiso para llevar en sus tocados y ropas la banda de oro "como la traían los caballeros de la Orden de la Banda", en premio al "esfuerzo varonil" que demostraron durante el sitio que en 1387 impuso a su ciudad el ejército anglo-luso de Juan de Gante, duque de Lancáster ${ }^{31}$.

La Banda fue también conferida por los reyes castellanos a numerosos caballeros extranjeros, para consolidar las alianzas diplomáticas a través del consabido juramento de lealtad. De este modo, en 1457 Enrique IV admitió en ella al caballero suabo Jorge de Einghen y al austriaco Jorge de Ramyden, los cuales vistieron túnica escarlata con "una banda dorada de dos dedos de anchura"32. Todavía el 9 de julio de 1485, Fernando el Católico mandó ejecutar una Provisión Real ${ }^{33}$ en favor de Gil Rodríguez, vecino de Madrid, por la cual le eximió del pago de impuestos y le concedió el derecho a poner "la mi divisa de la Vanda" en todas sus "armas e ropas e guarniçiones", para sí y sus descendientes, como recompensa al arrojo demostrado en el sitio de Ronda, durante el cual fue armado caballero.

\section{LA MUY NOBLE Y HONORABLE OR- DEN DE LA JARRETERA.}

En 1337 comienza la Guerra de los Cien Años entre Francia e Inglaterra. La causa principal del conflicto reside en que el rey Eduardo III de Inglaterra reclama el trono de Francia en nombre de su madre, Isabel de Francia, por ser la única hija superviviente del rey francés Felipe

\footnotetext{
${ }^{31}$ G. J. OSMA, ob. cit., 1909, p. 45

32 J. GARCíA MERCADAL, Viajes de extranjeros por España y Portugal, I, Madrid, 1952, p. 248.

33 A. Millares Carlo, "Índice y extractos del libro horadado del Concejo madrileño. Siglos XV y XVI", Revista de la Biblioteca, Archivo y Museo del Ayuntamiento de Madrid, 1, 1924, p. 77
} 
IV el Hermoso. Argumenta que la Ley Sálica sólo es válida al este del río Sala, es decir, en la mitad oriental, ahora alemana, del fenecido Imperio Carolingio. Para justificar su pretensión utiliza interesadamente la leyenda del rey Arturo, recordando que, tras derrotar a los sajones, el héroe britano combatió en Francia contra el Imperio Romano esgrimiendo el derecho del usurpador Máximo, un general britano que en 383 se había proclamado emperador y que en 388 había sido derrotado y ejecutado por Teodosio I el Grande. En efecto, la Historia regum Britanniae $^{34}$ apunta que Arturo conquistó la Galia en nueve años y que París se rindió sin presentarle batalla. Después regresó a Britania y fue coronado de nuevo en Silchester, pero Roma le exigió el pago de los tributos establecidos desde el tiempo de Julio César. En respuesta, Arturo argumentó que tenía vínculos de cosanguinidad con Constantino y Máximo, los cuales habían sido reyes de Britania antes de ser emperadores de Roma, de modo que era él quien exigía ahora a Roma el pago de tributos. Seguidamente, Arturo derrotó a las legiones romanas en la Galia, pero la traición de su sobrino Mordred le obligó a regresar a Britania.

Para consolidar su empresa bélica en Francia, Eduardo III necesitaba asegurarse la lealtad de sus propios nobles mediante lazos más profundos y duraderos que los que podía proporcionar una simple alianza de intereses. Por ello, en diciembre de 1343 concibió el proyecto de refundar la antigua hermandad de la Tabla Redonda en el Castillo de Windsor ${ }^{35}$, apelando al sentimiento "nacional" britano y reutilizando la figura del rey Arturo para glorificar a la dinastía de los Plantagenet. Esta nueva Orden estaría formada por doscientos caballeros y se constituiría bajo el patronato de la Virgen María y de San Jorge. No sólo se inspiraba en el Ciclo Artúrico, sino que también tomaba como ejemplo a la Orden de la Banda que fundara once años antes Alfonso XI de Castilla. De hecho, sabemos que acababan de regresar a Inglaterra dos condes ingleses que en otoño de 1343 habían combatido contra los moros en el sitio de Algeciras, al servicio del monarca caste-

${ }^{34}$ G. DE MONMOUTH, ob. cit., 1994, pp. 155-187.

35 A. Murimuth, Continuatio chronicarum, 13041347, ed. de E. M. Thompson, Oxford, 1889, p. 232. Crónica citada en: H. E. L. Collins, The Order of the Garter 1348-1461. Chivalry and Politics in Late Medieval England, Oxford-Nueva York, 2000, pp. 6-10. llano. Se trataba de Enrique Plantagenet, conde de Derby, y de Guillermo de Montagu, II conde de Salisbury, los cuales debieron glosar ante el soberano inglés las excelencias ceremoniales y caballerescas de la nueva Orden castellana, cuyos miembros se distinguían tanto en las lides del torneo como en la cruzada ${ }^{36}$.

Sea como fuere, en enero de 1344 se celebraron unas suntuosas justas en el castillo de Windsor, para celebrar el regresó del monarca inglés a la isla después de su victoriosa campaña en la Bretaña francesa. El tercer día de las fiestas, después de oír misa en la capilla palatina, Eduardo III anunció a los nobles y damas de la corte su intención de fundar una Tabla Redonda "de la misma manera que Lord Arthur, antiguo rey de Inglaterra, la había tenido",37. Dijo también que la nueva Orden estaría formada por trescientos caballeros que se reunirían bajo su presidencia una vez al año, que sería en la semana de Pentecostés ${ }^{38}$, como ocurría en la Tabla Redonda del Roman de Brut. Para ello proyectaba construir en el castillo de Windsor un nuevo edificio circular ${ }^{39}$ de 60 metros de diámetro, formado por dos muros concéntricos y techados que encerrarían un gran espacio central a cielo abierto, donde se colocaría la Mesa Redonda. Las obras comenzaron el 16 de febrero 1344 e incluso llegó a construirse una gran mesa redonda de madera, que podría ser la conservada actualmente en el castillo de Winchester.

Este ambicioso proyecto constructivo fue pospuesto y posteriormente abandonado, debido al recrudecimiento de la guerra en Francia.

-

${ }^{36}$ De hecho, el conde de Derby fundó el 18 de enero de 1344 la Fraternidad de Justadores de Lincolnshire, inspirándose en la Orden de la Banda. Véase: J. D'ARCY BOULTON, The Knights of the Crown. The Monarchical Orders of Knighthood in Later Medieval Europe, 1325-1520, Woodbridge, 1987, pp. 109-110; H. E. L. COLLINS, ob. cit., 2000, p. 8 .

37 A. Murimuth, Continuatio..., ob. cit., 1889, p. 232. "mensam rotundam inciperet, eodem modo et statu quo eam dimisit dominus Arthurus quondam rex Angliae, scilicet ad numerum trecentorum militum". Citado en: H. E. L. COLLINS, ob. cit., 2000, pp. 6-7.

${ }^{38}$ G. LE BAKER, Chronicon, ed. de E. M. Thompson, Oxford, 1889, p. 279. Citado en: H. E. L. Collins, ob. cit., 2000 , p. 7.

${ }^{39}$ T. WALSINGHAM, Chronicon Angliae... autore monacho quodam Sancti Albani, 1328-88, ed. de E. M. Thompson, Londres, 1874, p. 17. Citado en: H. E. L. Collins, $o b$. cit., 2000, p. 7. Véase también: H. M. Colvin (ed.), The History of the King's Works, vol. 2, Londres, 1963, pp. 871872 . 
Eduardo III partió hacia el continente y las dificultades económicas obligaron a pensar en una orden caballeresca más barata. Tras la victoria de Crécy (1346) y la toma de Calais (1348), Eduardo III regresó a Inglaterra, habiendo decidido que su nueva Orden de caballería tendría un carácter más cristiano. Abandonó la denominación de "Tabla Redonda", que contenía significados semipaganos de origen céltico, y se deshizo, en parte, de una leyenda que celebraba el enfrentamiento con Roma, pero sin cercenar en modo alguno el espíritu caballeresco que la inspiraba. La nueva hermandad se llamaría "Orden de la Jarretera" ${ }^{40}$; sus patronos serían la Virgen María, San Jorge y San Eduardo el Confesor, y sus caballeros se reunirían en una iglesia colegial que se construiría en el castillo de Windsor. Por esta razón, Eduardo III instituyó el Colegio de San Jorge, gobernado por un deán o guardián y servido por doce canónigos, quince vicarios, cuatro secretarios, seis maestros cantores, un portero y veintiséis caballeros veteranos o "poor knights". Estos "caballeros pobres" eran elegidos entre los ancianos nobles que habían destacado por sus servicios militares a la corona.

La Orden de la Jarretera fue fundada el 23 de abril de 1348 por Eduardo III en el castillo de Windsor. Al año siguiente se redactaron Estatutos $^{41}$ en latín y en francés, y se fijó el número de caballeros en veintiséis, incluyendo al príncipe de Gales y al propio rey, que sería el maestre. La nueva Orden estaría gobernada por tres oficiales ${ }^{42}$, que serían un prelado -el obispo de Winchester-, un guardián del sello de la Orden y un "register" o secretario administrativo. Enrique $\mathrm{V}$ añadió un cuarto oficial en la persona del rey de armas "Garter" o "Jarretière"43, cargo heráldico creado en 1417 para potenciar el prestigio de la Orden y para presidir el cuerpo de oficiales de armas de Inglaterra. Fue su primer titular William Bruges, antiguo rey de armas "Guyenne". Finalmente, y a imitación de la Orden del Toisón de oro, Eduardo IV institu-

${ }^{40}$ H. E. L. COLLINS, ob. cit., 2000, pp. 11-24

${ }^{41}$ L. JEFFERSON, "Two Fifteenth-Century Manuscripts of the Order of the Garter", en: P. BEAL Y J. GRIFFITHS (eds.), English Manuscript Studies, 1100-1700, Londres, 1995, pp. 18-35; H. E. L. Collins, ob. cit., 2000, pp. 14-19, 24-27.

${ }^{42}$ H. E. L. COLLINS, ob. cit., 2000, pp. 30-32

${ }^{43}$ H. S. LONDON, The Life of William Bruges, the First Garter King of Arms, Harleian Society, Londres, 1970; H. E. L. COLLINS, ob. cit., 2000, pp. 32, 228, 231, 246, 262. yó en 1474 el oficio de canciller de la Orden, que sería ejercido de modo honorífico por el obispo de Salisbury.

Como distintivo de la Orden se adoptó una divisa militar ${ }^{44}$ que había sido utilizada por los caballeros ingleses en la victoria de Crécy. Se trataba de un cinturón militar con su hebilla atada y anudada (Fig. 7), simbolizando los lazos de lealtad y amistad que debían unir a los caballeros. Dicho cinturón se llevaría atado bajo la rodilla izquierda, a modo de liga o jarretera, como distintivo masculino que cumplía una función similar a la que tenía la banda dorada en Castilla. Los colores elegidos fueron los de Francia, azul y oro, simbolizando la legitimidad de la pretensión de los Plantagenet al trono francés. Sobre el terciopelo azul de la Jarretera podía leerse, en letras de oro y lengua francesa, el lema o mote "HONI SOIT QUI MAL Y PEN$S E$ " ("Mal haya quien mal piense"), que fue concebido para desafiar a quienes dudaran de la legitimidad de tal pretensión.

Esta divisa figuraría también en el hábito de los caballeros (Fig. 8), compuesto de túnica carmesí sembrada de jarreteras azules y de una larga capa de terciopelo azul que en el lado del corazón llevaba bordado un escudo de San Jorge (de plata, cruz de gules), rodeado por una jarretera circular con su lema escrito en caracteres góticos. De este modo seguía estando presente la combinación de cruz y círculo, propia de las viejas cruces esculpidas anglo-irlandesas. Así vestidos, se reunirían en capítulo cada 23 de abril, día de San Jorge, en los asientos de la sillería de coro de la nueva capilla de San Jorge y de la Virgen María del Castillo de Windsor, cuya construcción se inició el 6 de agosto de 1348. En abril de ese año se había celebrado la ceremonia inaugural en otra parte del castillo, confiriendo el rey las primeras veinticuatro ligas, además de la suya propia. Diez años más tarde sería establecida la Fraternidad de Damas de San Jorge ${ }^{45}$, siendo la propia reina, Felipa de Hainaut, la primera mujer que recibió la divisa de la Jarretera.

Cada caballero de la Jarretera ocuparía su lugar en una sillería de coro de planta rectangular (Fig. 9) que estaría adornada con los bla-

\footnotetext{
44 J. VALE, Edward III and Chivalry. Chivalric Society and its context, 1270-1350, Woodbridge, 1982, pp. 79-82.

${ }^{45}$ H. E. L. COLLINS, ob. cit., 2000, pp. 28, 301-303.
} 
sones respectivos, puestos en una bandera situada sobre cada asiento y en una placa esmaltada fijada al respaldo del mismo. Los asientos principales, dispuestos a ambos lados de la entrada del coro, serían para el rey y para el príncipe de Gales. De este modo, estaba garantizada la precedencia simbólica del monarca inglés, que en una mesa redonda hubiese quedado democráticamente diluida entre sus pares. En realidad, esta cristianización del proyecto inicial se debió a que el Papa de Aviñón desaprobaba las órdenes caballerescas que únicamente se dedicaban a la actividad profana y peligrosa de los torneos. Además, con la celebración del sacramento de la Eucaristía, quedaba asegurada la visión simbólica del Santo Grial.

Cada capítulo duraba tres días ${ }^{46}$, repartidos como sigue. El 22 de abril se reunían los caballeros en Windsor a la hora tercia, a fin de discutir los asuntos de la Orden, de analizar las actividades de sus componentes durante el año precedente y de proceder a la elección de nuevos miembros. La reunión podía continuar después del rezo de vísperas. El 23 de abril, festividad de San Jorge, los caballeros oían misa mayor en la sillería de la capilla colegial y el monarca entregaba la liga a los nuevos miembros de la Orden. A continuación se celebraba un banquete en la gran sala del palacio y al anochecer se acudía a vísperas en la capilla. El 24 de abril se cantaba una solemne misa de "requiem" en memoria de los caballeros fallecidos y se daba por concluido el capítulo.

La Orden de la Jarretera se convirtió en el principal instrumento simbólico a través del cual se garantizó la lealtad de la alta nobleza inglesa a su corona. Además, desde 1400 se utilizó como medio para sellar pactos internacionales en la lucha contra Francia, mediante la admisión de caballeros extranjeros ${ }^{47}$. Ese año, el rey Enrique IV de Inglaterra envió la Jarretera a los reyes don Enrique III de Castilla y don João I de Portugal. Treinta años más tarde, Enrique VI de Inglaterra otorgó la Jarretera al rey don Duarte de Portugal, a los duques de Coimbra y Viseu y a don Alvaro Vaz d'Almada, duque de Avranches. En años sucesivos recibieron la distinción Carlos el Temerario, duque de Borgoña; los reyes Alfonso V de Portugal, Alfonso V de Aragón y de Nápoles y Casimiro IV de

\footnotetext{
${ }^{46}$ Ibid., 2000, pp. 23-24.

${ }^{47}$ Ibid., 2000, pp. 177-186.
}

Polonia; el emperador Federico III de Alemania, Federico de Montefeltro, duque de Urbino; los reyes Fernando el Católico y Felipe I el Hermoso, el emperador Carlos V y el rey Felipe II de España. En la actualidad es la única orden medieval de caballería que sobrevive en Europa conservando intactos sus estatutos y ceremonias. Cada 23 de abril, día de San Jorge, renueva el espíritu legendario de la Tabla Redonda en la espléndida capilla de San Jorge del castillo de Windsor, reconstruida en tiempos del rey Enrique VII Tudor.

\section{LA MUY NOBLE ORDEN DEL TOISÓN DE ORO.}

La Orden del Toisón de oro ${ }^{48}$ señala el colofón de todo el proceso. Su origen fue netamente político, pues estuvo motivado porque en 1422 Juan Plantagenet, duque de Bedford y regente de Francia, ofreció la Jarretera a su aliado Felipe el Bueno, duque de Borgoña, con la finalidad de reforzar la alianza diplomática angloborgoñona $^{49}$. Si Felipe aceptaba esta distinción, se vería obligado a jurar fidelidad al rey Enrique VI de Inglaterra y de Francia, soberano de la Orden inglesa, lo que le colocaría en una embarazosa situación de dependencia con respecto a éste. Rechazó por ello el ofrecimiento, argumentando que deseaba fundar su propia Orden caballeresca.

Fiel a su promesa, Felipe el Bueno fundó la Orden del Toisón de oro el 10 de enero de 1430 en la villa flamenca de Brujas ${ }^{50}$, durante los festejos de su boda con la infanta Isabel de Portugal. A imitación del modelo inglés, eligió dos patronos, que fueron San Andrés y la Vir-

\footnotetext{
${ }^{48}$ Sobre la Orden del Toisón de oro, véase: G. FILLASTRE, Histoire de la Toison d'or, París, 1516; B. MoLINET, La Toison d'or ou recueil des statuts et ordonnance du noble Ordre, Colonia, 1689; BARÓN DE REIFFENBERG, Histoire de l'Ordre de la Toison d'or, Bruselas, 1830; H. KERVYN DE LETTENHOVE, La Toison d'or, Brujas, 1907; A. VAN ZUYLEN VAN Nyvelt, L'Ordre de la Toison d'or à Bruges, Brujas, 1929; MARQUÉS DE CÁRDENAS, El Toisón de oro, Orden dinástica de los Duques de Borgoña, Madrid, 1960; C. TERLINDEN, La Toison d'or. Cinq Siècles d'Art et d'Histoire, Brujas, 1962; H. FILliTZ (coord.), Tresors de la Toison d'or. Europalia 87 Österreich, Bruselas, 1987; R. DOMÍNGUEZ CASAS, Arte y Etiqueta de los Reyes Católicos, Madrid, 1993, pp. 655-699; J.L. LIEZ (dir.), La Toison d'or. Un mythe européen, Paris-Metz, 1998, pp. 219-222.

${ }^{49}$ G. Chastelain, Oeuvres, ed. de J. Kervyn de Lettenhove, Bruselas, II, 1863-1866, pp. 9-15; D. REGNIERBOHLER (dir.), Splendeurs de la Cour de Bourgogne. Récits et Chroniques, París, 1995, pp. 778-781.

${ }^{50}$ G. Chastelain, ob. cit., 1863-1866, pp. 5-8; D. RÉGNIER-BOHLER, ob. cit., 1995, p. 776.
} 
gen María, y dispuso que la Orden estaría formada por veinticuatro caballeros más el soberano, que sería él mismo. Esta nueva Orden sería administrada por cuatro oficiales: un canciller, que sería siempre un prelado; un "greffier" o secretario, un tesorero que custodiaría las vestiduras y collares, y un rey de armas que sería "Toison d'or", decano de los oficiales de armas de Borgoña.

Esta Orden sería estrictamente masculina, por ser Borgoña tierra sálica. Pero distanciándose de los ejemplos precedentes, Felipe el Bueno buscó para ella otro patrono en el Ciclo Troyano $^{51} \mathrm{y}$, más concretamente, en el Roman de Troie, obra escrita hacia 1184 por Benoît de Saint-Maure. Este libro comenzaba relatando la historia de Jasón y los Argonautas, a la que convertía en el primer acto de la Guerra de Troya. El motivo de la elección de Jasón como patrono de la Orden borgoñona reside en que este héroe había viajado con los Argonautas desde Grecia hasta la Cólcida, en la actual Georgia, donde recuperó el Vellocino de oro después de derrotar a dos toros y al dragón que lo custodiaba. De este modo, el Toisón de oro se convertía en el símbolo de Jerusalén, ciudad santa que debía ser rescatada de manos islámicas por el duque de Borgoña y sus caballeros mediante una cruzada, en la que derrotarían a los dos toros, símbolo de la carne y del mundo, y darían muerte al dragón, símbolo del demonio y del mal.

Pero Jasón era un pagano de dudosa conducta, ladrón por hurtar el Vellocino y perjuro al romper su compromiso matrimonial con Medea. Por esta razón, en el primer capítulo de la Orden, celebrado en Lille en 1431, el canciller Jean Germain, obispo de Nevers, buscó otro patrono ${ }^{52}$ más acorde con la ética cristiana, reparando en la historia de la incredulidad de Gedeón que figuraba en el Antiguo Testamento

\section{-}

51 Sobre el Ciclo Troyano en la corte de Borgoña, véase: A. BAYOT, "La Legende de Troie à la cour de Bourgogne", Mélanges de la Societé d'Émulation de Bruges, t. I, Brujas, 1908; M. CHEYNS-CONDE, "L’Épopée Troyenne dans la $<<$ librairie $>>$ ducale bourguignonne au XVe siècle", en: J.-M. CAuChIES (ed.), A la cour de Bourgogne. Le Duc, son entourage, son train, Burgundica, t. I, Turnhout, 1998, pp. 85-114; C. VAN DEN BERGEN-PANTENS, "El Vellocino de oro y sus mitos", en: M. A. ZALAMA Y P. VANDENBROECK (dirs.), Felipe I el Hermoso. La belleza y la locura, Madrid, 2006, pp. 105-115.

${ }^{52}$ G. Doutrepont, "Jason et Gédéon, patrons de la Toison d'or", Mélanges offerts à Godefroid Kurth, ParísLieja, 1908, pp. 191-208; J.-L. LIEZ (dir.), ob. cit., 1998, pp. 62-84.
(Jueces 6, 34-38). Mediante dos pruebas nocturnas, el Vellocino de Gedeón vaticinó la victoria del Pueblo de Dios sobre los Madianitas. Del mismo modo, al ser elegido como patrono de la Orden borgoñona, el héroe bíblico anunciaba la victoria sobre el Islam. Su Vellocino, de vedijas blancas y espolvoreadas de rocío celestial, pasaba a ser el símbolo de la pureza virginal de María, bajo cuya protección se fundó esta hermandad caballeresca.

La insignia de la Orden borgoñona no fue una liga o una banda, sino un collar de oro (Fig. 10) de veinticuatro eslabones inspirados en la divisa personal del duque -el Fusil con forma de "B" de Borgoña y el pedernal chispeante-, del que pendía una imagen del Vellocino de oro, como símbolo del compromiso de cruzada adquirido por el soberano y sus caballeros. En un principio vistieron túnica talar de lana púrpura, pero Carlos el Temerario introdujo en 1473 chaperón y mantos de terciopelo carmesí, cuyas cenefas, bordadas en oro, contenían la divisa borgoñona unida a su lema personal, “ $J E L$ ' $A I$ EMPRINS" ("Yo lo emprendí"), alusivo a su deseo de iniciar la cruzada.

Los Estatutos de la Orden ${ }^{53}$ obligaban a celebrar una reunión cada 30 de noviembre, día de San Andrés, en el lugar donde se encontrase el soberano. Las reuniones capitulares (Fig. 11) no eran anuales, pero todos los caballeros estaban obligados a asistir a ellas. Cuando las hubiere, se celebrarían durante los cuatro primeros días de mayo en una de las ciudades de los dominios ducales, aunque la sede perpetua de la Orden estaba en la "Sainte-Chapelle" del palacio de Dijon ${ }^{54}$. Los caballeros acudirían en procesión desde el palacio hasta la catedral o iglesia principal del lugar, tomando asiento en la sillería de coro, en cuyos respaldos figurarían

-

${ }^{53}$ Los Estatutos del Toisón de oro pueden consultarse en: B. ViCENS Y GIL DE TEJADA, Historia de las órdenes de caballería y de las condecoraciones españolas: Orden del Toisón de oro, t. 1.2, Madrid, 1864, pp. 467-508. Están traducidos literalmente de la obra del Barón de Reiffenberg. Véase también: O. DE LA MARCHE, "Espitre pour tenir et célébrer la noble feste du Thoison d'or", Mémories, t. IV, París, 1883-1888, pp. 158-189. Este autor describe el ceremonial de la época de Carlos el Temerario. Véase también: R. DOMÍNGUEZ CASAS, "Estilo y rituales de corte", en: M. A. ZALAMA Y P. VANDENBROECK (dirs.), ob. cit., 2006, pp. 99-103.

${ }^{54}$ P. QuARre, "La Chapelle du Duc de Bourgogne à Dijon, $<<$ lieu et chapitre et collège $>>$ de l'Ordre de la Toison d'or', Publication du Centre Européen d'Etudes Burgundo-médianes, Lovaina, 1962, pp. 56-64. 
sus escudos de armas, dispuestos en riguroso orden de antigüedad. Allí oirían misa durante esos cuatro días, en honor, sucesivamente, de San Andrés, de los caballeros difuntos, del Espíritu Santo y de la Virgen María. En tiempo de Carlos el Temerario se redujo el festejo a tres días, quedando suprimida la misa del Espíritu Santo. Después de cada misa se celebraba en palacio un gran banquete, cuyo solemne ceremonial se inspiraba en la liturgia eucarística. El cuarto día se reunía el soberano con los caballeros de la Orden en una sala privada del palacio ("chambre du conclave"), donde se procedía al examen de la conducta moral que había llevado cada uno -incluido el soberano- desde el capítulo anterior, siguiendo un proceso inquisitivo que fue introducido por Carlos el Temerario y que no existía en la Orden de la Jarretera. Finalmente se procedía a la entrega de collares a los nuevos cofrades.

La función política de la Orden del Toisón de oro era más compleja que la ofrecida en los casos inglés y castellano, pues Felipe el Bueno $^{55}$ se sirvió de ella para arrancar un juramento de lealtad a los principales aristócratas de su estado plurinacional y plurilingüe. Su hijo y sucesor, Carlos el Temerario ${ }^{56}$, utilizó el creciente prestigio de la Orden borgoñona para afianzar alianzas internacionales, admitiendo en ella a varios reyes y príncipes extranjeros, entre los que se contaba Fernando el Católico. Este proceso culminó en el capítulo barcelonés ${ }^{57}$ de 1519, cuando Carlos I de España, como duque de Borgoña, aumentó a cincuenta el número de caballeros para admitir a los principales aristócratas alemanes, italianos y españoles, de sus enormes dominios. El fin político de este suntuoso teatro de caballeros consistía en reunir en torno al emperador a la élite de los territorios por él gobernados. La Fe cristiana y el examen de conducta a que obligaban los Estatutos, garantizaba de sus componentes un comporta-

55 W. PARAVICINI, "Expansion et intégration. La noblesse des Pays-Bas à la cour de Philippe le Bon", Bijdragen en Mededelingen Betreffende de Geschiedenis der Nederlanden, $\mathrm{n}^{\circ} 95,2$, 1980, pp. 298-314.

56 Véase: R. DE SMEDT (dir.), Les Chevaliers de l'Ordre de la Toison d'or au XVe siècle, Frankfurt am Main, 2000; A. CeBAllos (dir.), La Insigne Orden del Toisón de oro, Madrid, 2000, pp. 231-273.

${ }^{57}$ R. DOMÍNGUEZ CASAS, "Arte y simbología en el capítulo barcelonés de la Orden del Toisón de oro (1519)", en: A. TOURNEUX Y J. PAVIOT (dirs.), Liber amicorum Raphaël de Smedt. Miscellanea Neerlandica, vol. II, Artium Historia, XXIV, Lovaina, 2001, pp. 173-204. miento caballeroso que rehuía toda actitud tiránica, como señalaba con precisión el modelo arquetípico de Arturo y sus caballeros de la Tabla Redonda. No en vano, cuando los cabreros inquieren a Don Quijote de la Mancha sobre cómo definiría al caballero andante, este responde sin titubear:

“No han vuestras mercedes leido los anales e historias de Inglaterra, donde se tratan las famosas fazañas del Rey Arturo, que continuamente en nuestro romance castellano llamamos el rey Artús?... Pues en tiempo de este buen rey fue instituida aquella famosa orden de caballería de los caballeros de la Tabla Redonda, y pasaron, sin faltar un punto, los amores que alli se cuentan de don Lanzarote del Lago con la reina Ginebra, siendo medianera de ellos y sabedora aquella tan honrada dueña Quintañona, de donde nació aquel tan sabio romance, y tan decantado en nuestra España, de:
Nunca fuera caballero
de damas tan bien servido
como fuera Lanzarote
cuando de Bretaña vino". 


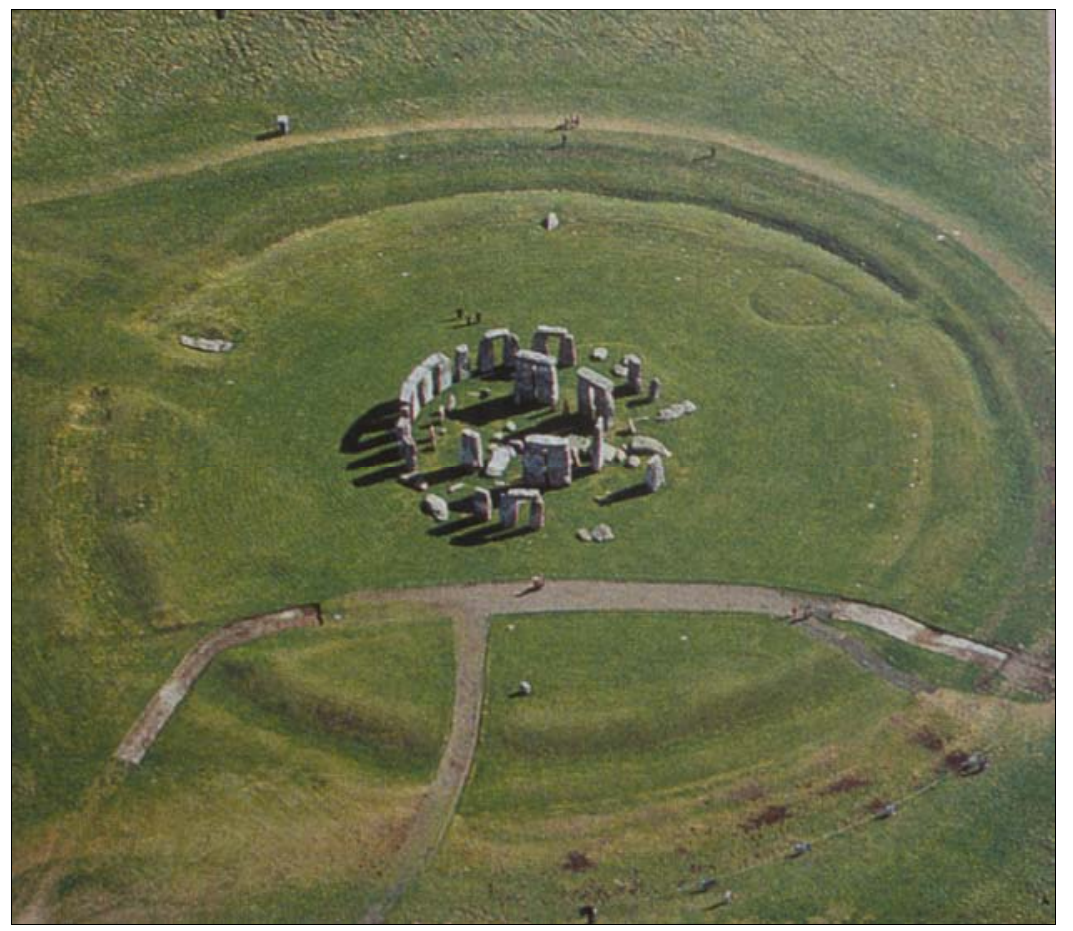

- $\quad$ Fig. 1. Wiltshire (Inglaterra). Crómlech de Stonehenge (ss. XIV-XII a. C.).
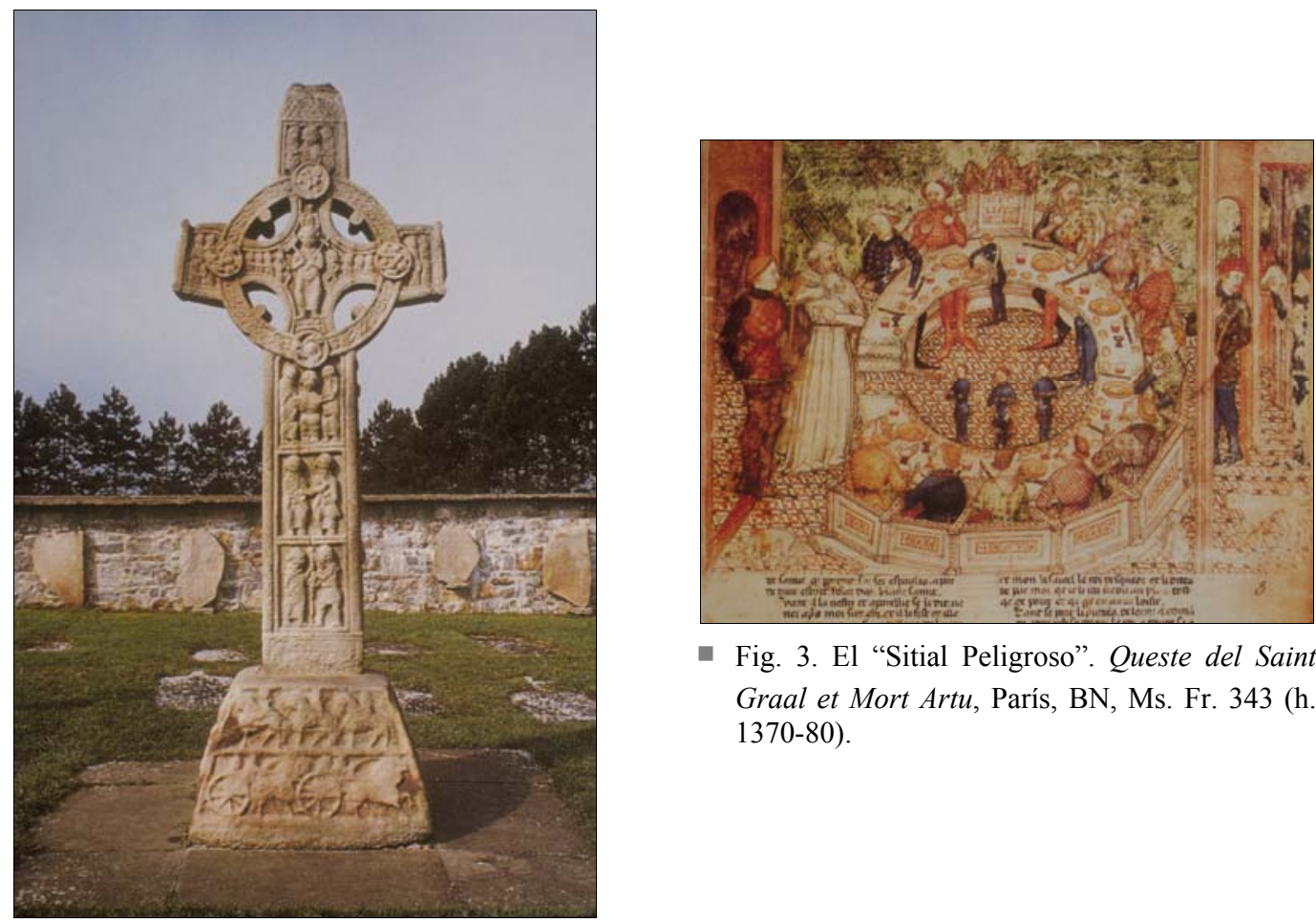

- Fig. 3. El "Sitial Peligroso". Queste del Saint Graal et Mort Artu, París, BN, Ms. Fr. 343 (h. 1370-80).

- Fig. 2. Irlanda. Cruz de Clonmacnoise (s. X). 


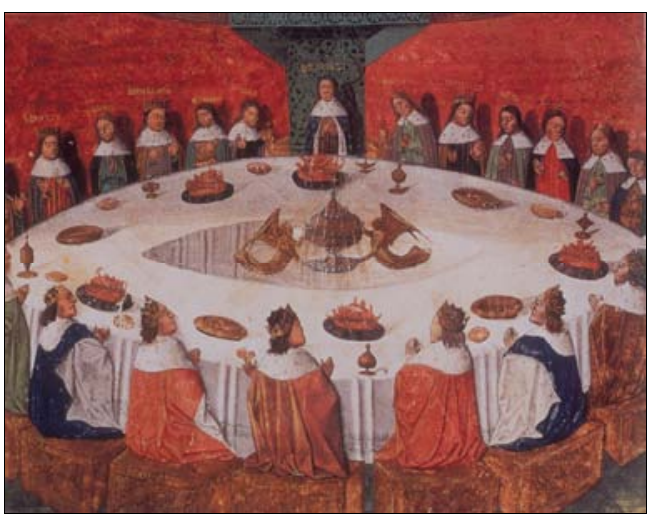

- Fig. 4. Aparición del Santo Grial. Lancelot, París, BN, Ms. Fr. 112 (h. 1470).

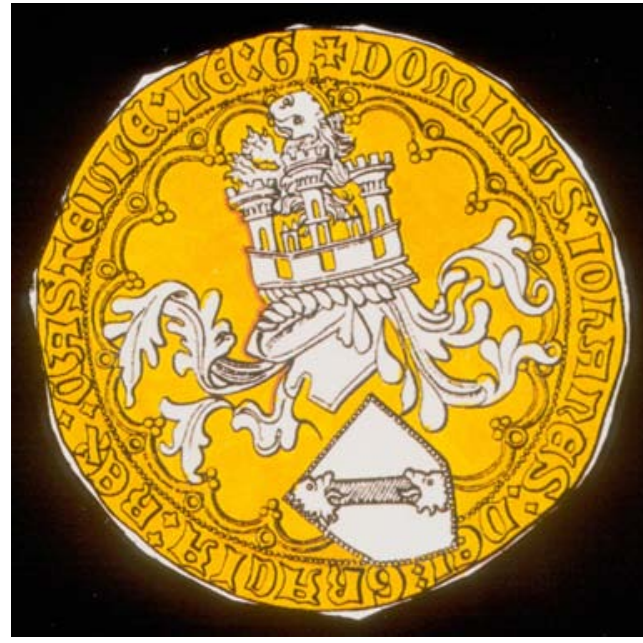

- Fig. 5. Divisa de la Banda Real de Castilla.

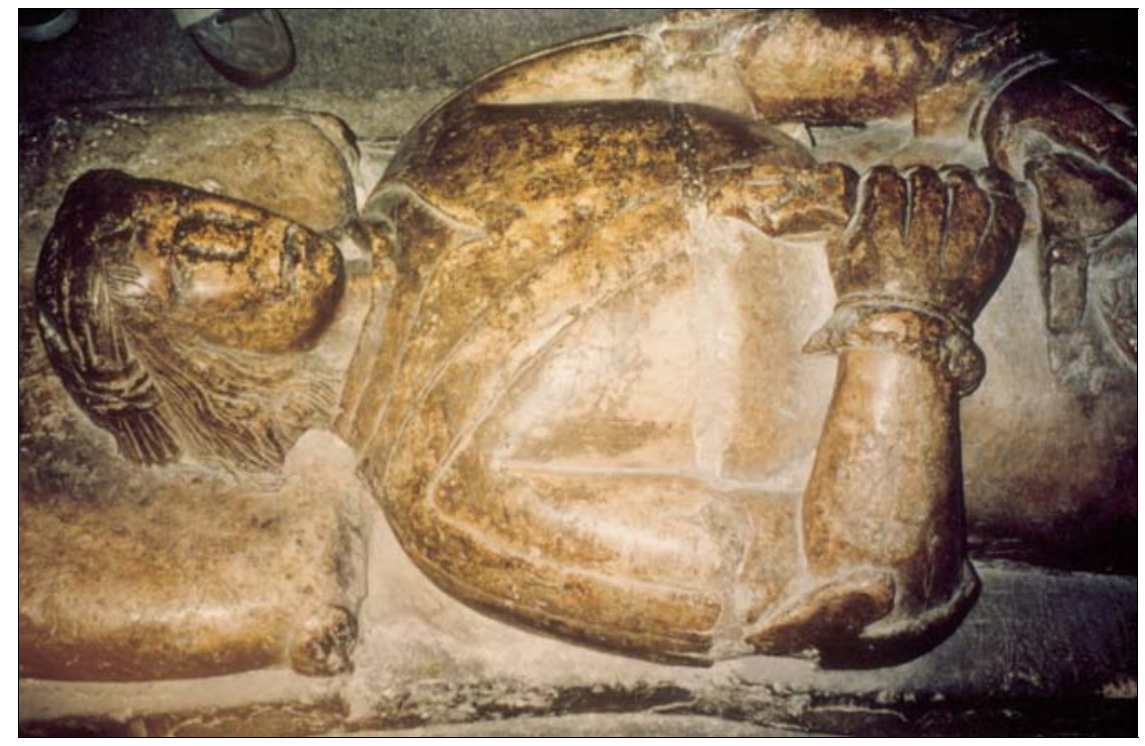

- Fig. 6. Burgos. Catedral. Caballero de la Banda (s. XV).

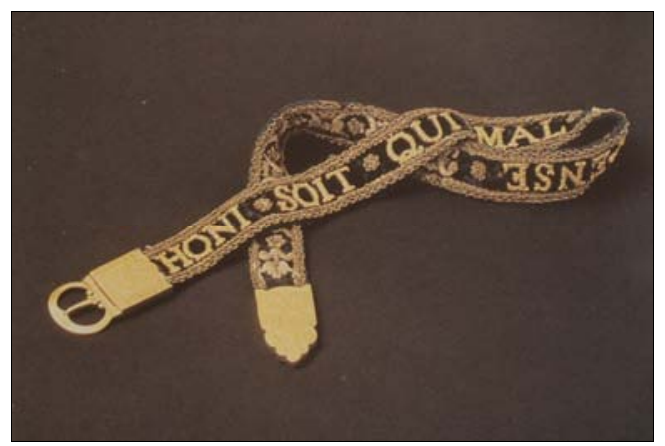

- Fig. 7. Divisa de la Orden de la Jarretera. 


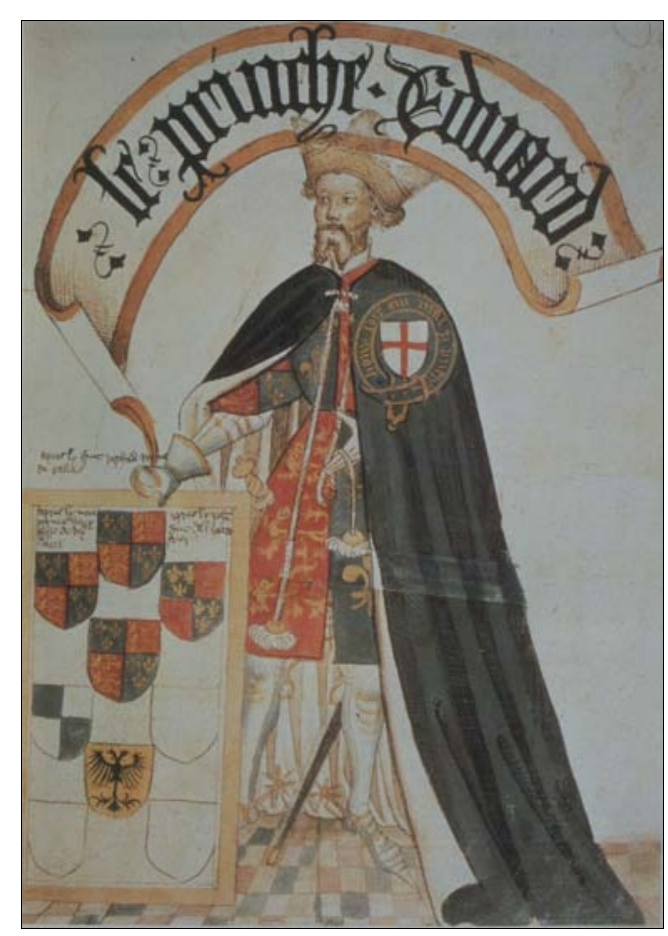

- Fig. 8. El Príncipe Negro en hábito de la Jarretera. William Bruges's Garter Book, Londres, BL Stowe MS 594 (h. 1440-50).

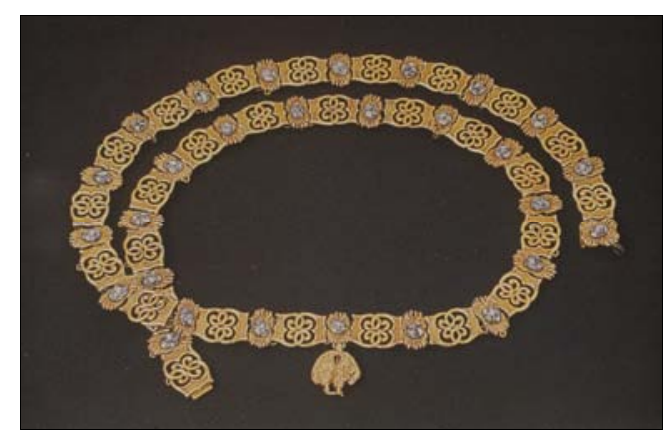

- Fig. 10. Collar del Toisón de oro.

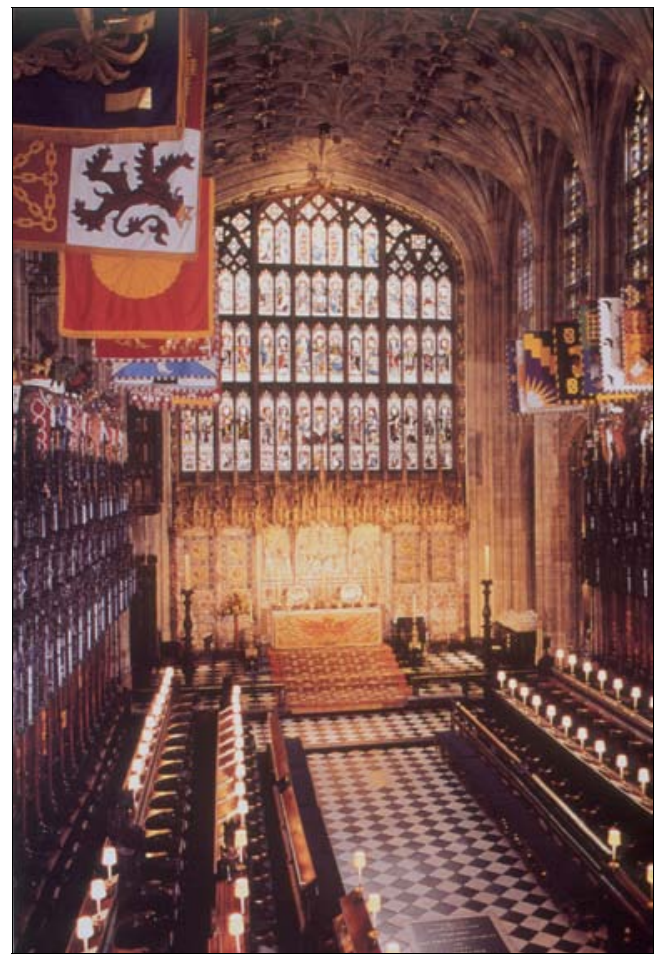

- Fig. 9. Windsor. Castillo. Capilla de San Jorge. Interior (1481-1511).

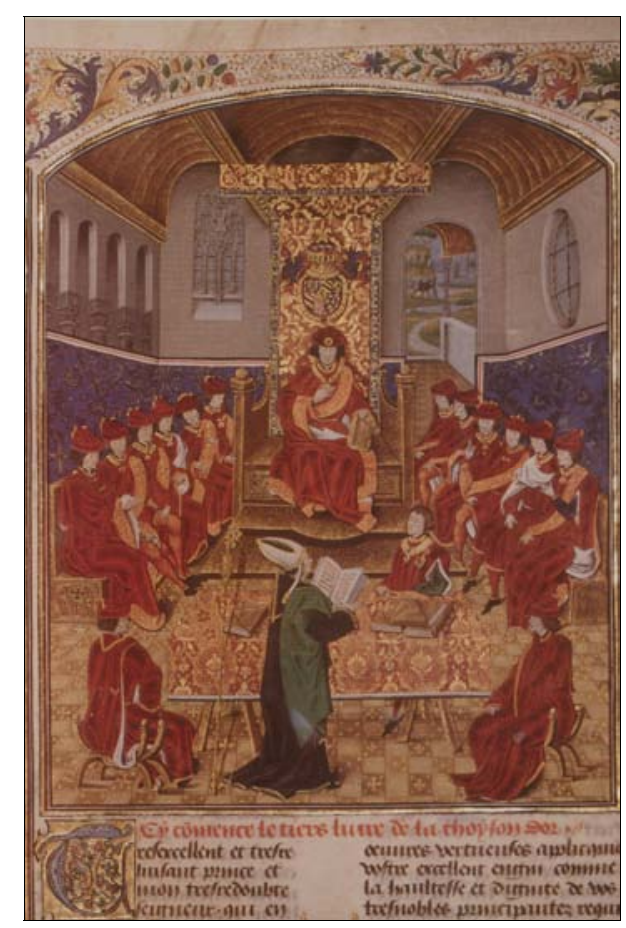

- Fig. 11. Capítulo del Toisón de oro. Guillaume Fillastre, Le troisième livre de la Toison d'or, Copenhague, KB, cod. Thott 465 (h. 1470). 